\title{
Method for rearing Cladomorphus phyllinus Gray, 1835 (Phasmatodea: Phasmatidae) under laboratory conditions
}

\author{
Caio C. Truzi ${ }^{ \pm=(\mathbb{D}}$, Natalia F. Vieira ${ }^{\mathbb{D}}$, Joice M. de Souza ${ }^{(}$, Beatriz Ferracini $^{\circledR}$, Sergio A. De \\ Bortoli ${ }^{(\infty)}$
}

Department of Agricultural Production Sciences (Crop Protection), São Paulo State University (FCAV-Unesp), Jaboticabal, SP, Brazil. 拝=“Corresponding author: caio_truzi@hotmail.com

Edited by: Sandra M. M. Rodrigues

Received: September 20, 2020. Accepted: October 26, 2020. Published: December 11, 2020.

\begin{abstract}
Cladomorphus phyllinus Gray, 1835 (Phasmatodea: Phasmatidae) is a species of stick bug native to Brazil and considered one of the largest in the southern hemisphere. The rearing method described uses rectangular cages for the maintenance of nymph and adult insects, with feeding carried out with guava leaves. This method promotes the multiplication of insects, which have been used for educational purposes.
\end{abstract}

Keywords: Stick bug, rearing method, guava.

The insects of the order Phasmatodea stand out for their camouflage, they are morphologically similar to sticks, branches, leaves and hence are popularly known as stick bug or leaf bug (Bedford 1978). These insects are mostly phytophagous and have a wide geographic distribution with the exception of polar regions, with the largest number of species being found in tropical and subtropical regions (Bedford 1978; Aliaga 2015).

These insects are poorly studied (Bradley \& Galil 1977; Zompro 2001; Chiquetto-Machado \& Albertoni 2017), and most of the studies involve taxonomic approaches and species description (Costa Lima 1938; Toledo Piza 1944; Zompro \& Domenico 2005; Hennemann et al. 2016; Kumagai \& Fonseca 2009; Heleodoro et al. 2017), others assess biological and ecological aspects (Zapata \& Torres 1970; Dorval et al. 2003; Sottoriva et al. 2008; Alvarenga et al. 2018). In addition we have some researches on the digestive system (Azevedo et al. 2013; Monteiro et al. 2014).

Cladomorphus phyllinus Gray, 1835 (Phasmatodea: Phasmatidae) is native to Brazil and considered one of the largest species in lenght in the southern hemisphere, with females reaching up to $22 \mathrm{~cm}$ (Brock 1992). Males are shorter, reaching up to $15 \mathrm{~cm}$ in length and are winged, differing from females that are apterous (Fig. 1) (Costa Lima 1938; Kumagai \& Fonseca 2009). This phasmid feeds on leaves of several fruit trees (Brock 1992), however it prefers plants of the Myrtaceae family (Sottoriva et al. 2008). The incubation period for C. phyllinus is over 100 days, while nymph development can take up to 180 days. In adulthood, males live around 127 days and females 208 days, with a fecundity of 390 eggs (Monteiro et al. 2014).

The method for rearing $C$. phyllinus started for educational purposes, in the Laboratory of Biology and Insect Rearing (LBIR), Department of Agricultural Production Sciences (Crop Protection), São Paulo State University (Unesp), Jaboticabal, São Paulo. However according to Cohen (2015) and De Bortoli et al. (2017) an adequate rearing method facilitates the multiplication of insects and studies in several areas. The rearing started with nymphs obtained from the Department of Entomology and Acarology, of the "Luiz de Queiroz" College of Agriculture (ESALQ), Piracicaba, São Paulo. The development of all phases occurs under laboratory-controlled conditions at $25 \pm 1{ }^{\circ} \mathrm{C}$, $70 \pm 10 \% \mathrm{RH}$ and 12:12 h (light:dark) photoperiod.

The phasmids are kept in rectangular glass cages $(40.0 \mathrm{~cm}$ lenght $\times 30.0 \mathrm{~cm}$ wide $\times 31.0$ height) (Fig. 2) which has one side open and are closed with voile fabric, fastened with elastic or paper clip, allowing for a better aeration. About 40 insects are kept in this cage at the beginning of the nymphal phase, decreasing during development and reaching 10 insects in the adult phase. The cages are lined with brown paper to facilitate the removal of excrement and the collection of eggs.
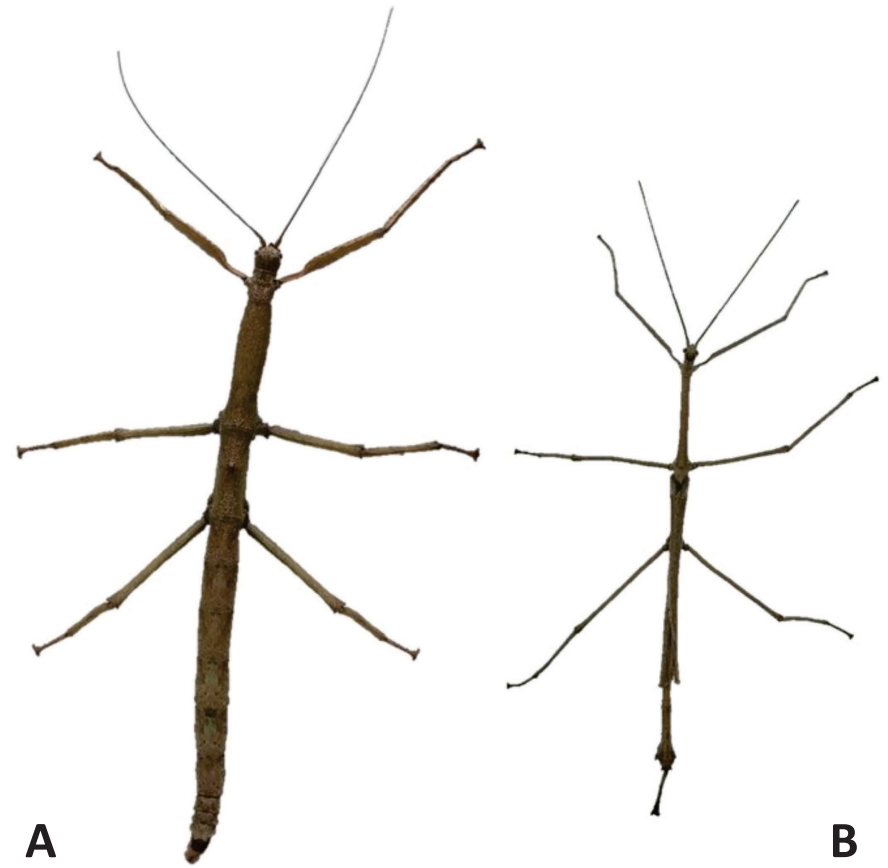

Figure 1. Cladomorphus phyllinus adults. A) Female; B) Male.

C. phyllinus are fed with guava leaves, a plant of the Myrtaceae family. The branches with leaves are collected, washed with water and placed in a $200 \mathrm{~mL}$ container, filled with water, placed in the center of the rearing cage. The water in the container is topped up after 3-4 days in order to maintain the leaves turgid for a longer period of time, while the leaves are replaced after 7 days or when they begin to dry. When this time period is completed, the eggs are collected and the cages are cleaned up (Fig. 2).

Eggs are collected with tweezers and transferred to Petri dishes left without lids $(6.0 \mathrm{~cm}$ diameter $\times 2.0 \mathrm{~cm}$ height), which are arranged in 


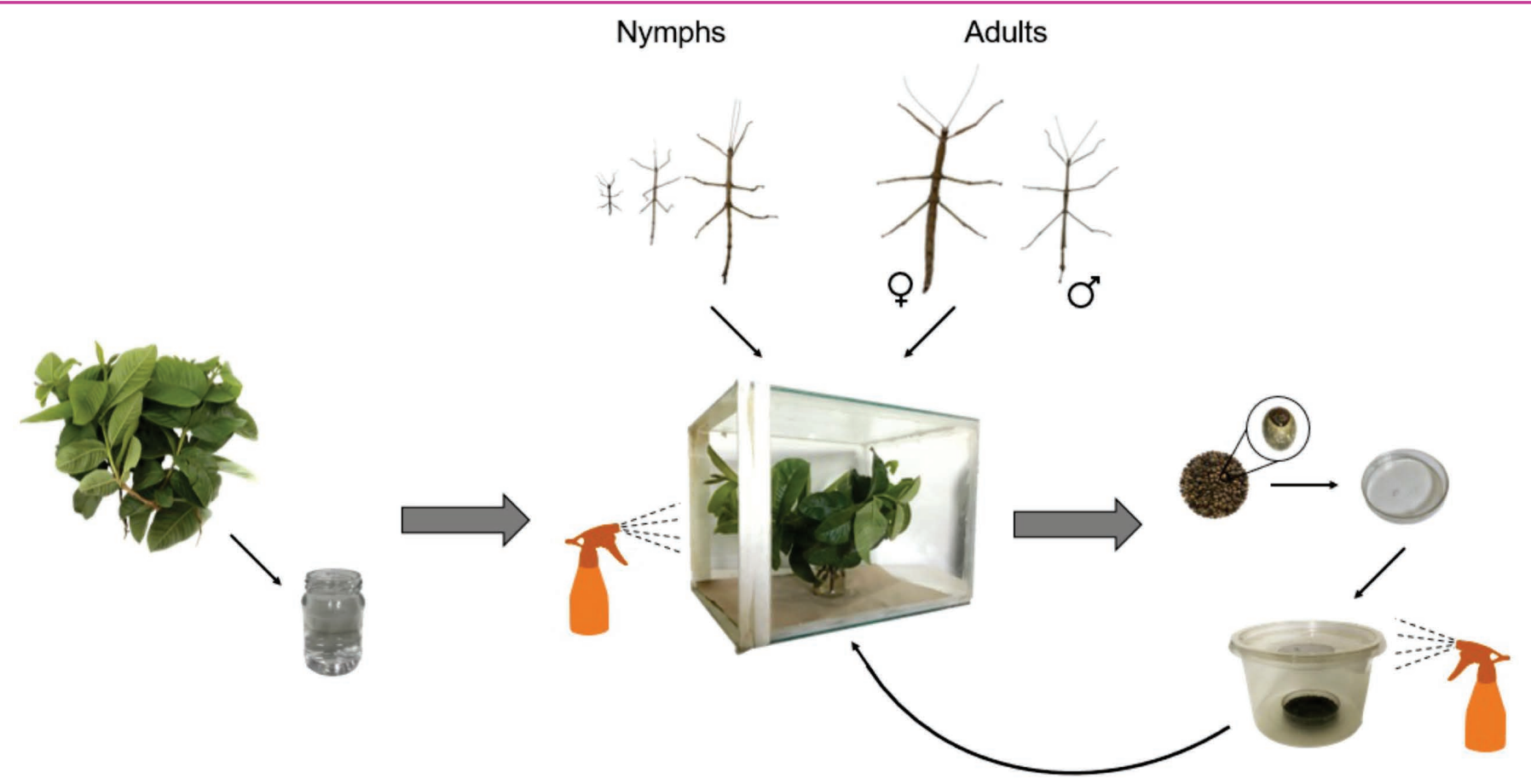

Figure 2. Scheme of the method for rearing Cladomorphus phyllinus under laboratory conditions.

transparent plastic containers (15.0 diameter $\times 9.0 \mathrm{~cm}$ height) (Fig. 2). The top of the container has a hole $(5.0 \mathrm{~cm}$ diameter) covered with voile fabric for better internal aeration. After the first nymph hatch, the Petri dish containing the eggs is transferred to the rearing cages. Every 2 days, water is sprayed both in the cages and in containers with eggs, for maintaining humidity and also providing water to insects (Fig. 2).

The order Phasmatodea comprises, for the most part, nocturnal insects that stay in shaded trees (Bedford 1978). In this sense, a black fabric is used to cover the cage top to simulate the common habitat and improve the insect development (Fig. 3). Alternatives to the rearing glass cage are ones crafted with acrylic or wood. However it is important that at least one wall is substituted by voile fabric to allow a proper aeration. This method has been carried out for more than 2 years, allowing the multiplication of stick bugs that are used in events of pedagogical purpose, where children and teenagers have the opportunity to observe and touch these insects.

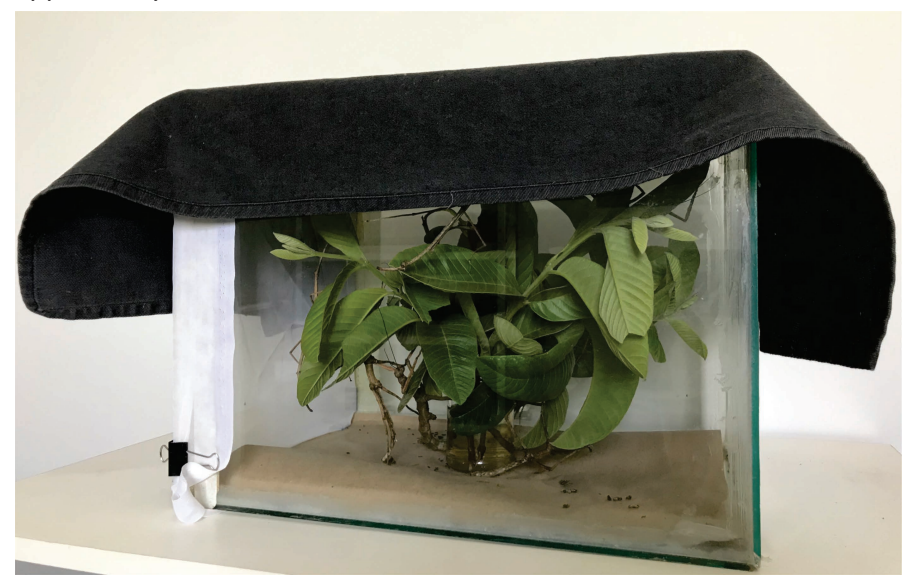

Figure 3. Rearing cage of Cladomorphus phyllinus covered with black fabric.

\section{Authors' Contributions}

CCT conducted the rearing and wrote the manuscript; NFV, JMS and $\mathrm{BF}$ conducted the rearing; $\mathrm{SAB}$ revised the manuscript.

\section{References}

Aliaga, M. M. (2015) Orden Phasmatodea. Revista IDE@ - SEA, 45: 1-11. Alvarenga, C. D.; Souza, H. R.; Giustolin, T. A.; Matrangolo, C. A. R.; Silva, J. F. (2018) Biologia de Cladomorphus phyllinus Gray
(Phasmatodea: Phasmatidae) em folhas de goiabeira (Psidium guajava). EntomoBrasilis, 11(2): 65-69. doi: 10.12741/ebrasilis. v11i2.762

Azevedo, D. O.; Fialho, M. C. Q.; Vargas, N. C.; Vilela, E. F.; Zanuncio, J. C.; Serrão, J. E. (2013) Morphology of the digestive tract of Cladomorphus phyllinus (Phasmatodea: Phasmidae). Florida Entomologist, 96(4): 1417-1423. doi: 10.1653/024.096.0421

Bedford, G. O. (1978) Biology and ecology of the Phasmatodea. Annual Review of Entomology, 23: 125-149. doi: 10.1146/annurev. en.23.010178.001013

Bradley, J. C.; Galil, B. S. (1977) The taxonomic arrangement of the Phasmatodea with keys to the subfamilies and tribes. Proceedings of the Entomological Society of Washington, 79: 176-208.

Brock, P. D. (1992) Rearing and studying stick and leaf insects. London: Amateur Entomologists' Society.

Chiquetto-Machado, P. I.; Albertoni, F. F. (2017) Description of the female, egg and first instar nymph of the stick insect Paraphasma paulense (Phasmatodea: Pseudophasmatidae) from Southeast Brazil. Journal of Orthoptera Research, 26(2): 91-101. doi: 10.3897/ jor.26.20180

Cohen, A. C. (2015) Insect diets: Science and technology. Boca Raton: CRC Press.

Costa Lima, A. M. (1938) Insetos do Brasil. $1^{\circ}$ tomo. Rio de Janeiro: Escola Nacional de Agronomia.

De Bortoli, S. A.; Vacari, A. M.; De Bortoli, C. P. (2017) Criação de insetos: Passado, presente e futuro. In: Castilho, R. C.; Barilli, D. R.; Truzi, C. C. (Eds.), Tópicos em entomologia agrícola - X, pp.13-26. Jaboticabal: Gráfica Multipress Ltda.

Dorval, A.; Peres-Filho, O.; Moraes, C. S. P.; Berti-Filho, E. (2003) Biologia e estudo comportamental de Bacteria tuberculate Piza Jr., 1939 (Phasmatodea; Phasmatidae) em folhas de anjico (Piptenia spp.). Scientia Forestalis, 63: 150-157.

Heleodoro, R. A.; Mendes, D. M. M.; Rafael, J. A. (2017) Studies on Brazilian Pseudophasmatidae (Phasmatodea) with the description of a new species of Agrostia Redtenbacher and new records for Metriophasma Uvarov and Parastratocles Redtenbacher. Revista Brasileira de Entomologia, 61(2): 170-177. doi: 10.1016/j. rbe.2017.03.003

Hennemann, F. H.; Conle, O. V.; Perez-Gelabert, D. E. (2016) Studies of Neotropical Phasmatodea XVI: Revision of Haplopodini Günther, 1953 (rev. stat.), with notes on the subfamily Cladomorphinae Bradley and Galil, 1977 and the descriptions of a new tribe, four new genera and nine new species (Phasmatodea: "Anareolatae": 
Phasmatidae: Cladomorphinae). Zootaxa, 4128: 1-211. doi: 10.11646/zootaxa.4128.1.1

Kumagai, A. F.; Fonseca, N. G. (2009) Uma nova espécie de Cladomorphus Gray, 1835 (Phasmatidae, Cladomorphinae) de Minas Gerais. Revista Brasileira de Entomologia, 53(1): 41-44. doi: 10.1590/S0085-56262009000100011

Monteiro, E. C.; Tamaki, F. K.; Terra, W. R.; Ribeiro, A. F. (2014) The digestive system of the "stick bug" Cladomorphus phyllinus (Phasmida, Phasmatidae): A morphological, physiological and biochemical analysis. Arthropod Structure \& Development, 43: 123134. doi: 10.1016/j.asd.2013.11.005

Sottoriva, L. D. M.; Picolo, L.; Ramos, L. C. H.; Roel, A. R. (2008) Preferência alimentar e biologia reprodutiva do bicho-pau Phibalosoma phyllinum Gray, 1835 (Phasmatodea, Phasmatidae) em criações de laboratório. Multitemas (UCDB), 35: 135-148. doi: 10.20435/multi.v0i35.855

Toledo Piza, S. (1944) Cinco novas espécies de Phásmidas do Brasil. Anais da Escola Superior de Agricultura "Luiz de Queiroz", 1: 4358. doi: 10.1590/S0071-12761944000100004

Zapata, S.; Torres, E. (1970) Biologia y morfologia de Bacteria granullicolis (Blanchard) (Phasmida). Publicaciones del Centro de Estudios Entomológicos del Chile, 10: 23-42.

Zompro, O. (2001) A generic revision of the insect order Phasmatodea: the New World genera of the stick insect subfamily Diapheromeridae: Diapheromerinae $=$ Heteronemiidae: Heteronemiinae sensu Bradley \& Galil, 1977. Revue Suisse de Zoologie, 108: 189-255. doi: 10.5962/bhl.part.79626

Zompro, O.; Domenico, F. C. (2005) Catalogue of the type material of Phasmatodea (Insecta) deposited in Brazilian Museums. Inheringia, Série Zoologia, 95(3): 255-259. doi: 10.1590/S007347212005000300005 